\title{
The effects of the Panax Vietnamensis ethanol fraction on proliferation and differentiation of mouse neural stem cells
}

\author{
Huy Quang Do ${ }^{1 \#, ~ N h u n g ~ H a i ~ T r u o n g ~}{ }^{1,2 \#, ~ T h a n h ~ T h a i ~ L a m ~}{ }^{1}$, Linh Thuy Nguyen ${ }^{1}$, Dung Minh Le1, \\ Nhung Hong-Thi Dinh ${ }^{1}$, Luan Cong Tran ${ }^{3}$, Phuong Thi-Bich Le ${ }^{4}$, Ngoc Kim Phan ${ }^{1}$, Phuc Van Pham ${ }^{1,2,5, *(\odot) ~}$
}

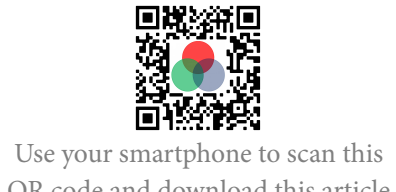

QR code and download this article

\section{\# equal contribution}

${ }^{1}$ Laboratory of Stem Cell Research and Application, University of Science, VNU-HCM, Ho Chi Minh City 70000, Viet Nam

${ }^{2}$ Biology Faculty, University of Science, VNU-HCM, Ho Chi Minh City 70000, Viet Nam

${ }^{3}$ Center of Ginseng and Medicinal materials, National Institute of Medicinal Materials (NIMM), Ho Chi Minh City 70000, Viet Nam

${ }^{4}$ Van Hanh General Hospital, Ho Chi Minh City, Viet Nam

${ }^{5}$ Stem Cell Institute, VNU-HCM University of Science, Viet Nam

\section{Correspondence}

Phuc Van Pham, Laboratory of Stem Cell Research and Application, University of Science, VNU-HCM, Ho Chi Minh City 70000, Viet Nam

Biology Faculty, University of Science, VNU-HCM, Ho Chi Minh City 70000 , Viet Nam

Stem Cell Institute, VNU-HCM University of Science, Viet Nam

Email: pvphuc@hcmuns.edu.vn

\section{History}

- Received: May 102019

- Accepted: Sept 282019

- Published: Oct 282019

DOI :

https://doi.org/10.15419/bmrat.v6i10.571

\section{Check for updates}

\section{Copyright}

(๑) Biomedpress. This is an openaccess article distributed under the terms of the Creative Commons Attribution 4.0 International license.

\begin{abstract}
Introduction: Panax vietnamensis Ha et Grushv. (Ngoc Linh ginseng) - a new species recently discovered in Vietnam - has received much interest due to its rich content of saponins, including those unknown. This study assessed the effects of the Ngoc Linh ginseng extract fractions on proliferation and differentiation of cultured mouse neural stem cells. Methods: Whole brains were harvested from E13.5-14 Swiss mouse fetuses. Isolated cells were floating seeded to form spheroid bodies. Neurospheres were treated with one in fractions of ethanol $200-500 \mu \mathrm{g} / \mathrm{mL}$, or $\mathrm{n}$-butanol $200 \mu \mathrm{g} / \mathrm{mL}$, or aqueous 200-500 $\mu \mathrm{g} / \mathrm{mL}$ for 5 days. Neural stem cells could persistently generate secondary spheres. Neurospheres strongly expressed nestin, CD24 and deriving cells could differentiate into the GFAP-positive astrocyte-like cells. Results: Ginseng fractions significantly promoted neurosphere growth rate. Particularly, $200 \mu \mathrm{g} / \mathrm{mL}$ ginseng ethanol fraction significantly increased the neurosphere size $(28.00 \pm 3.00 \%, \mathrm{p}<0.0001)$ not showing degeneration to the $5^{\text {th }}$ day. However, n-butanol and aqueous fraction could not sustain the sphere structure. Ginseng ethanol fraction also elevated in the G2/M proportion $(28.73 \pm 0.45 \%, \mathrm{p}<0.0001)$, up-regulated proliferation mRNA ki67 (4.605 \pm 6.48 fold-change, $p<0.05)$, cycA1 (12.61 \pm 4.65 fold-change, $p<0.0001)$, cycD1 $(22.47 \pm 8.18$ fold-change, $\mathrm{p}<0.0001), c y c C(9.53 \pm 2.63$ fold-change, $\mathrm{p}<0.0001)$ compared with those of the n-butanol or aqueous fraction-treated neurospheres. Shorten G0/G1 phase $(47.08 \pm 0.16$, $p<0.0001)$, up-regulation of sox2 $(71.25 \pm 27.24$ fold-change, $p<0.0001)$ mRNA levels indicated selfrenewal effect of the ginseng ethanol fraction; however, those of $n$-butanol and aqueous fractiontreated neurospheres suggested an inhibiting effect on the cell proliferation. Conclusion: Panax vietnamensis extract fractions had a positive effect on the proliferation of cultured neural stem cells. The ethanol fraction at $200 \mu \mathrm{g} / \mathrm{mL}$ could significantly promote the growth rate while still sustained the integrity of treated spheres.

Key words: Ethanol fraction, Mouse neural stem cells, NSCs, Panax vietnamensis, Stem cell proliferation
\end{abstract}

\section{INTRODUCTION}

In the Northeast and East Asian countries like Vietnam, Korea, and China, ginseng has been used thousands of years to enhance human health. Panax ginseng saponins were indicated improve Parkinsonian progress on animal models, cognitive performance of Alzheimer's patients and traumatic brain injuries ${ }^{1-3}$ due to regulating the neurotrophic factor-associated pathways ${ }^{4-6}$. Ginsenosides could promote the differentiation of neural stem cells ${ }^{7}$, enhancing the neuronal fate in cultured adipose-derived stem cells ${ }^{8}$. A significant source of ginseng saponins comes from popular species like $P$. ginseng C. A. Meyer, P. notoginseng, and $P$. quinquefolium. Recently, a new ginseng species - Panax vietnamensis - was found in Vietnam. New ginsenosides in P. vietnamensis were shown to ameliorate depression, neuronal oxidative stress and improve the cognitive performance in the mouse model ${ }^{9-13}$. However, these studies have poorly showed the effect of ginseng extracts on the in vitro neural stem cells.

Proliferating cells were discovered first in the rat brain by Altman, J. and G.D. Das ${ }^{14}$. Subsequently, neural stem cells (NSCs) from both animals and humans have been extensively studied and characterized both in vivo and in vitro ${ }^{15,16}$. In mammals, NSCs exist in both adult and embryonic brains at different developmental stages ${ }^{17}$. NSCs could differentiate into three functional cell types of the nervous system. Over the past decade, there has been a rising interest in the $3 \mathrm{D}$ culturing method for drug screening due to its mimicking the stem cell niche in the body ${ }^{18,19}$. Originally introduced by Reynolds and Weiss, the neurosphere culturing method has become a convenient model for screening pharmaceutical properties of substances on neural stem cells because it reduces the differentiation 
possibility compared to adherent NSCs ${ }^{20,21}$. In this study, we investigate the potential effects of $P$. vietnamensis extracts on cultured neurospheres. The proliferation and differentiation of neural stem cells were access to show the effects of $P$. vietnamensis extracts.

\section{MATERIALS-METHODS}

\section{Animal and experimental design}

This study was approved by our institutional ethical committee (Laboratory of Stem cell Research and Application, University of Science, VNU-HCM). Healthy, E13.5-15.5 pregnant Swiss mice were kept in a stable environment of 12 hours light-dark cycle in the Microventilation cage system (THREE-SHINE Inc., Korea) with ad libitum access to food and water and acclimated for 1 week before the operation.

\section{Plant material and preparation}

Five years of age Panax vietnamensis was provided by the Center of Ginseng and Medicinal materials, National Institute of Medicinal Materials (NIMM), Ho Chi Minh City, Vietnam. Crude extract of Panax vietnamensis was prepared following the same method previously published ${ }^{22}$. In brief, whole root and rhizome of the plant was air-dried and powdered. Firstly, ginseng powder was percolatively extracted using $96 \%, 48 \%, 24 \%$, and $0 \%$ ethanol (Merck, USA), respectively. Next, the extract solutions would be evaporated at low-pressure and lyophilized to yield the crude ethanol extract (shortly regarded as "the ethanol fraction"). Lipid in the extract was eliminated by ethyl ether. Next, ethyl ether was discarded from the product and water-saturated $n$-butanol was added. The $n$-butanol was collected and lyophilized to give the $n$-butanol fraction. Deinonized water was added to the remaining solution, next gathered and lyophilized to yield the aqueous fraction.

\section{Neural stem cells (NSCs) isolation and cul- ture}

The NSCs isolation and culture methods in this study were repeated those in our previous study ${ }^{23}$ with reference to the method described by Reynolds et al. and Zheng, X.-S., et al. ${ }^{17,24}$. E13.5-15 pregnant mice were deep anesthetized by $100 \mathrm{mg} / \mathrm{kg}$ of ketamine, and $16 \mathrm{mg} / \mathrm{kg}$ of xylazine and cervical dislocated. Fetal brains were isolated and homogenized into sterile PSBA solution. Brain pieces were digested with $0.025 \%$ trypsin $0.02 \%$ EDTA solution for $10 \mathrm{~min}$ utes at $37^{\circ} \mathrm{C}$. Trypsin inhibitor (Sigma- Aldrich, St Louis, MO) was used to stop the digestion. Single cells were collected through a $70 \mu \mathrm{m}$ Falcon cell strainer. About $2.10^{6}$ cells was suspended in $5 \mathrm{~mL}$ of basal NSC medium (serum-free DMEM/F12 high glucose, containing $30 \mu \mathrm{g} / \mathrm{mL}$ EGF, $30 \mu \mathrm{g} / \mathrm{mL}$ bFGF, $500 \mathrm{IU} / \mathrm{mL}$ heparin, $5 \mathrm{mg} / \mathrm{mL}$ insulin, $1 \mathrm{mg} / \mathrm{mL}$ transferrin, $0.01 \mathrm{mg} / \mathrm{ml}$ gentamicin) (all purchased from Sigma Aldrich, St Louis, MO), supplemented with $1 \mathrm{X}$ N-2 and 1X B-27 (Gibco ${ }^{\text {TM }}$, ThermoFisher Scientific, USA). Cells were seeded upon the agarose-covered $25 \mathrm{~cm}^{2}$ culture flask (Corning, USA) to prevent adhesion and cultured at $37^{\circ} \mathrm{C}, 5 \%$ of $\mathrm{CO}_{2}$. Medium was changed every 3 days.

\section{Sub-culture and sphere formation assay}

At confluence, all neurospheres or cell clumps were digested by $0.025 \%$ trypsin $0.02 \%$ EDTA solution for 10 minutes at $37^{\circ} \mathrm{C}$. Cell pellet was collected and resuspended in $5 \mathrm{~mL}$ of basal NSC medium.

For sphere formation assay, $\sim 1000$ single cells from neurospheres at passage $4^{\text {th }}$ were seeded into 24-well plate. Formation of new spheres was recorded.

\section{Immunocytochemistry}

To examine Nestin expression, passage $4^{\text {th }}$ neurospheres were collected, fixed in $1 \mathrm{~mL}$ of $1 \mathrm{X}$ FCM fixation buffer at RT, 30 mins and ice-cold, 5 mins $1 \mathrm{X}$ FCM permeabilization buffer (Santa Cruz Biotechnologies, USA). The sphere was incubated with $1^{\text {st }}$ rabbit anti-mouse nestin antibody (1: 200 N5413, Sigma Aldrich, Singapore), then FITC-conjugated $2^{\text {nd }}$ anti-Rb antibody (1:5000 ab6717, Abcam Singapore). Nuclei were stained with Hoescht 33342.

To examine GFAP expression, single cells from spheres were cultured in $2 \%$ FBS, EGF-free and bFGFfree basal NSC medium. Culture surface was covered with $50 \mu \mathrm{g} / \mathrm{mL}$ poly-L-Lysine to promote adhesion. After 10 days, spheres were fixed in FCM fixation buffer at RT for 5 minutes before being incubated with $1^{s t}$ rabbit anti-mouse GFAP antibody (1:100 ab16997, Abcam, Singapore) and rhodamineconjugated $2^{\text {nd }}$ anti-Rb antibody $(4 \mu \mathrm{g} / \mathrm{mL} \# 31670$ ThermoFisher Scientific, USA).

\section{Ginseng treatments}

For proliferation assay, $300 \mu \mathrm{m}$-diameter neurospheres ( $n=10$ spheres/each treatment) were used in ginseng treatment. The fraction was added to the basal medium with one of the concentrations 50 , 100, 200 or $500 \mu \mathrm{g} / \mathrm{mL}$ ). Basal NSC medium with or without $5 \mu \mathrm{g} / \mathrm{mL}$ nerve growth factor - NGF Sigma Aldrich, St Louis, MO) was used as the negative and positive control, respectively. Diameters of the neurospheres were recorded every day for 5 days. For 
differentiation assay, the neurospheres were first collected and transferred to an EGF- and bFGF-free basal NSC media which was supplemented with $200 \mu \mathrm{g} / \mathrm{mL}$ of ethanol, or $n$-butanol, or aqueous ginseng fraction. After 5 days, treated neurospheres were subjected to cell cycle analysis and gene expression.

\section{Flow cytometry}

Neurospheres were dissociated by $0.025 \%$ trypsin, $0.02 \%$ EDTA for 10 minutes at $37^{\circ} \mathrm{C}$. One million cells were incubated with $0.25 \mu \mathrm{g}$ FITC anti-mouse CD24 Antibody (Clone M1/69 BioLegend ${ }^{\circ}$ ). CD24 expression was analyzed by the FACSCalibur flow cytometer Biosciences and CellQuest Pro software (BD Biosciences, USA).

To analyze the cell cycle phase, cells were fixed with FCM fixation buffer (RT, 30 minutes) and ice-cold FCM permeabilization buffer (5 minutes), treated with $550 \mathrm{U} / \mathrm{mL}$ RNase A (Thermo Fisher Scientific, USA) at $37^{\circ} \mathrm{C}$ in 30 minutes. The cells were stained with $50 \mu \mathrm{g} / \mathrm{mL}$ PI (BD Biosciences, USA) at $37^{\circ} \mathrm{C}$, nolight for 20-30 minutes. The DNA content was analyzed by the FACSCalibur flow cytometer BD Biosciences and CellQuest Pro software.

\section{Quantitative RT-PCR}

Total neurosphere RNA was extracted using EasyBLUE Total RNA Extraction Kit (iNtRON Biotechnology, South Korea). Real-time RT-PCR analyses were performed using Brilliant III Ultra-Fast SYBR ${ }^{\circ}$ Green qPCR Master Mix (Agilent, USA). Expression of cell cycle $(k i 67, c y c A 1, c y c D 1, c y c C)$ and NSC markers (map2, gfap, $m b p$, sox2) genes were evaluated using Mastercycler Ep Realplex (Eppendorf, Germany). Levels of expression were analyzed using Livak-method $\left(2^{-\Delta \Delta C t}\right)$.

\section{Statistical analysis}

Data in this study was presented as mean \pm SEM and analyzed by GraphPad Prism 6.0 software. Differences amongst treated groups were analyzed by twoway ANOVA followed by post-hoc Tukey's multiple comparisons methods. Differences would be considered statistically significant when $\mathrm{p}$-value $\leq 0.05$.

\section{RESULTS}

Spheroid bodies emerging from floating cells expressed neural stem cells markers

Three days since seeding, round-shape clumps of cell were seen in the culture (Figure 1A,B) ${ }^{23}$. Sphere formation assay showed that cells when seperated from the sphere could form new ones (Figure 1B,C).
Cells inside spheres were Nestin-positive for neural stem/progenitor marker (Figure 2) and CD24positive by flow cytometry analysis (Figure 3 ). As withdrawing EGF and bFGF as well as adding fetal bovine serum to the basal NSC medium, cells adhering upon the surface were GFAP-positive (Figure 4).

High concentration of $\boldsymbol{n}$-butanol was nonneurotrophic, not sustaining the structure of cultured neurospheres

The $n$-butanol fraction $500 \mu \mathrm{g} / \mathrm{mL}$ was unable to maintain the integrity of cultured neurospheres (Figure 5), characterized with scattered cells and dark borders. However, ethanol and aqueous fractions at concentrations did not cause any significant neurosphere deformity. Low concentrations $(50,100,200$ $\mu \mathrm{g} / \mathrm{mL}$ ) of the $n$-butanol fraction seemed not toxic for the neurospheres.

Panax vietnamensis ethanol fraction 200 $\mu \mathrm{g} / \mathrm{mL}$ could maintain the growth rate of treated neurospheres

At day 4, the basal NSC medium (control) sphere diameter reached the final enlargement of $17 \pm 4 \%$. At day $4 n$-butanol $200 \mu \mathrm{g} / \mathrm{mL}$ and aqueous fraction 200 or $500 \mu \mathrm{g} / \mathrm{mL}$ significantly increased the sphere diameter compared to the control: $n$-butanol - 30.7.4 $\pm 4.23 \% \quad(\mathrm{p} \leq 0.001)$, aqueous fraction 200 $\mu \mathrm{g} / \mathrm{mL}-23.78 \pm 7.99 \%(\mathrm{p} \leq 0.01)$, aqueous fraction $500 \mu \mathrm{g} / \mathrm{mL}-22.98 \pm 7.99 \%(\mathrm{p} \leq 0.01)$. However, there was no significant difference between the control and ethanol fraction $200 \mu \mathrm{g} / \mathrm{mL}$ neurosphere. At day 5, ethanol fraction $200 \mu \mathrm{g} / \mathrm{mL}$ increased the sphere diameter by approx. $28 \pm 3 \%$ ( $\mathrm{p} \leq 0.001)$, and no noticeable deformity of treated spheres was seen (Figure 6). No difference was between the growth rate of basal NSC medium and ethanol $/ n$-butanol fractions 50 or $100 \mu \mathrm{g} / \mathrm{mL}$.

For the integrity in neurosphere structure, those treated with $200 \mu \mathrm{g} / \mathrm{mL} n$-butanol fraction (Figure 7) or $500 \mu \mathrm{g} / \mathrm{mL}$ aqueous fraction (Figure 8) could not maintain the whole structure at the end of the experiment. These spheres were characterized with loose cells around the border, eventually adhering upon the surface. Interestingly, treated neurospheres had a high and stable rate of diameter increase in the first three days, and began to degrade afterward significantly. 


\begin{tabular}{|c|c|c|}
\hline Gene & Primer sequence $\left(5^{\prime}-3^{\prime}\right)$ & Genes \\
\hline \multirow[t]{2}{*}{ gapdh } & F: AAGTTGTCATGGATGACC & NM_001289726.1 \\
\hline & R: TCACCATCTTCCAGGAGC & \\
\hline \multirow[t]{2}{*}{$k i-67$} & F: GCAGGAAGCAACAGATGAGAAGCC & NM_001081117.2 \\
\hline & R: GCTCAGGTGATACATGCCTCCTGC & \\
\hline \multirow[t]{2}{*}{$c y c A 1$} & F: GTTTCCCCAATGCTGGTTGA & NM_001305221.1 \\
\hline & R: AACCAAAATCCGTTGCTTCCT & \\
\hline \multirow[t]{2}{*}{$c y c D 1$} & F: CCAGAGGCGGATGAGAACAA & NM_007631.2 \\
\hline & R: ATGGAGGGTGGGTTGGAAAT & \\
\hline \multirow[t]{2}{*}{$c y c \mathrm{C}$} & F: CAGGACATGGGCCAGGAA & NM_001290420.1 \\
\hline & R: TCCGTCCTGTAGGTATCATTCACTATC & \\
\hline \multirow[t]{2}{*}{ map2 } & F: GGCACTCСТCCAAGCTACTCT & NM_001310634.1 \\
\hline & R: CTTGACGTTCTTCAGGTCTGG & \\
\hline \multirow[t]{2}{*}{ gfap } & F: AACCGCATCACCATTCCTGT & NM_010277.3 \\
\hline & R: ACCTCACCATCCCGCATCT & \\
\hline \multirow[t]{2}{*}{$m b p$} & F: CTATAAATCGGCTCACAAGG & NM_001025258.2 \\
\hline & R: AGGCGGTTATATTAAGAAGC & \\
\hline \multirow[t]{2}{*}{ sox 2} & F: AAGGGTTCTTGCTGGGTTTT & NM_011443.4 \\
\hline & R: AGACCACGAAAACGGTCTTG & \\
\hline
\end{tabular}

F: Forward; R: Reverse
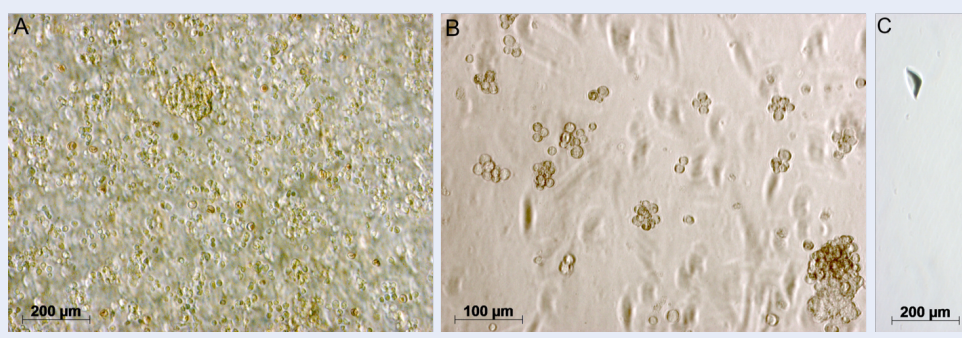

Figure 1: Neural stem cell culture. (A) A sphere forming in primary culture (B) New cell clumps in secondary culture (C) A secondary neurosphere forming from cells of primary neurospheres.
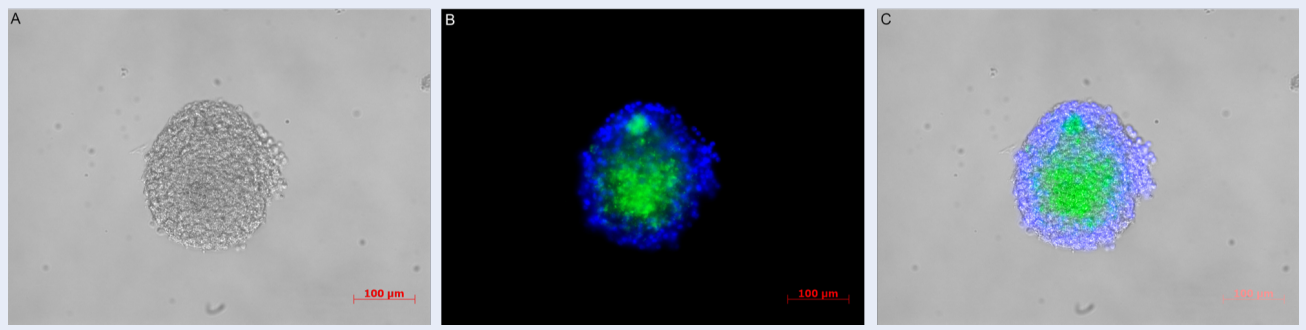

Figure 2: Nestin-positive neurosphere. (A) Bright-field (B) Merged: nestin - FITC, nucleus - Hoescht33342 (C) Superimposed. 

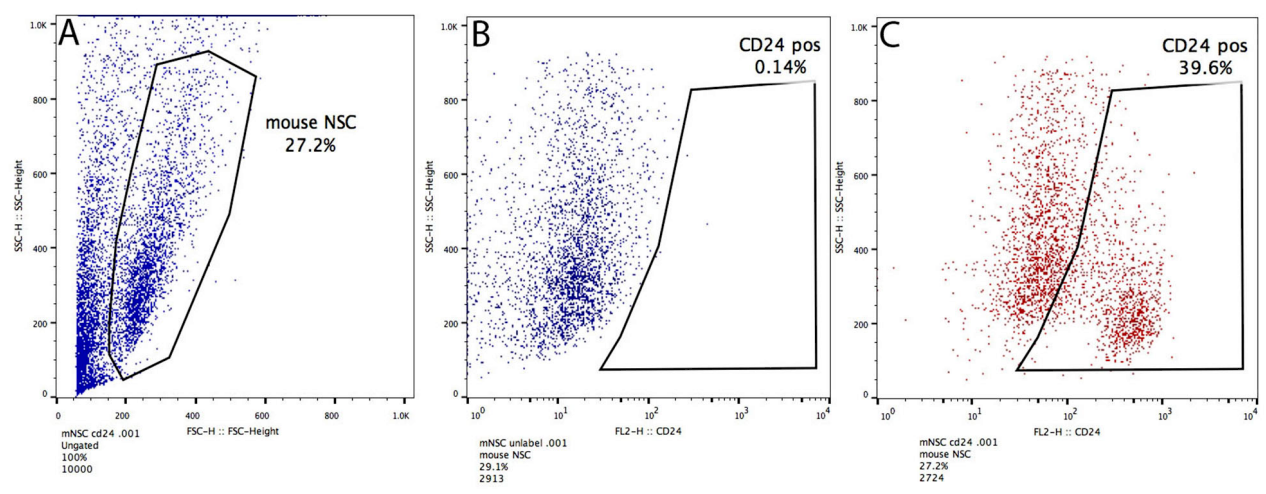

Figure 3: CD24-positive population in cultured neurosphere (A) Cells isolated from cultured neurospheres; (B) Unlabelled; (C) CD24-positive cells in the population.
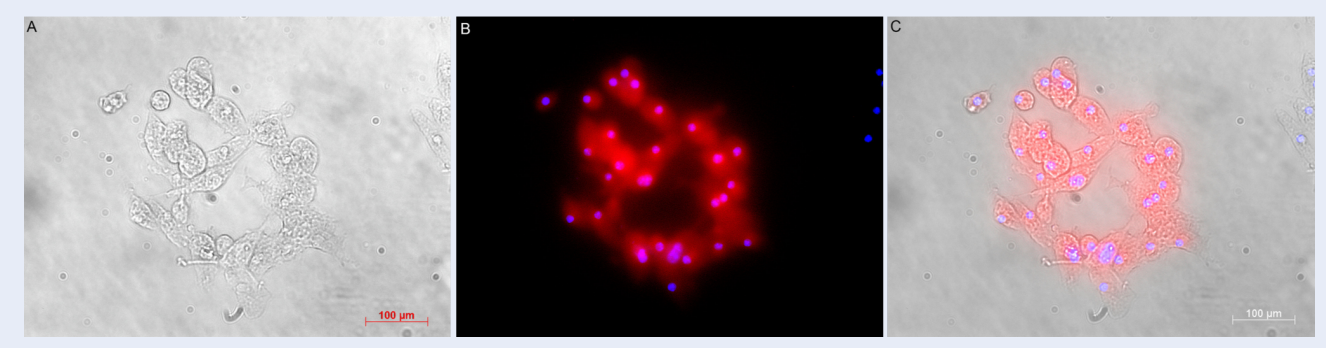

Figure 4: Glial fibrillary acidic protein (GFAP) expression in differentiation-induced neural stem cells (A) Bright-field (B) Intracellular expression of GFAP - rhodamine, nucleus- Hoescht 33342 (C) Superimposed image

A

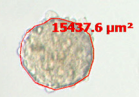

B

$$
200 \mu \mathrm{m}
$$

$200 \mu \mathrm{m}$

Figure 5: Sphere intergrity treated with $n$-butanol fraction $500 \mu \mathrm{g} / \mathrm{mL}$ (A) The sphere after treating for one day, and (B) degraded with its cells dispersed, lost its entire structure on day 2. 
Table 2: Summary of the treated neurosphere condition

\begin{tabular}{lcc}
\hline Fractions & $\begin{array}{c}\text { Concentration } \\
(\mu \mathbf{g} / \mathbf{m L})\end{array}$ & Neurotrophic \\
$n$-butanol & 500 & + \\
& $50-200$ & + \\
Aqueous & $50-500$ & + \\
Ethanol & $50-500$ & + \\
\hline
\end{tabular}

(-) non-neurotrophic; (+) maintain development until the final day

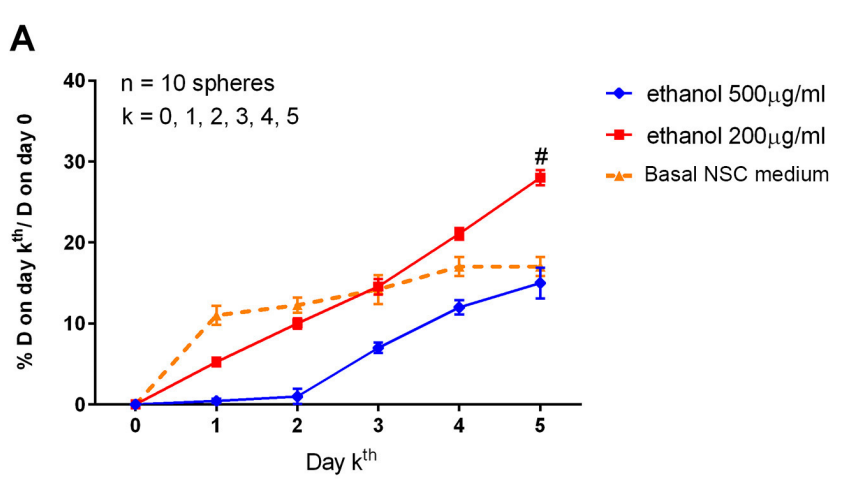

B

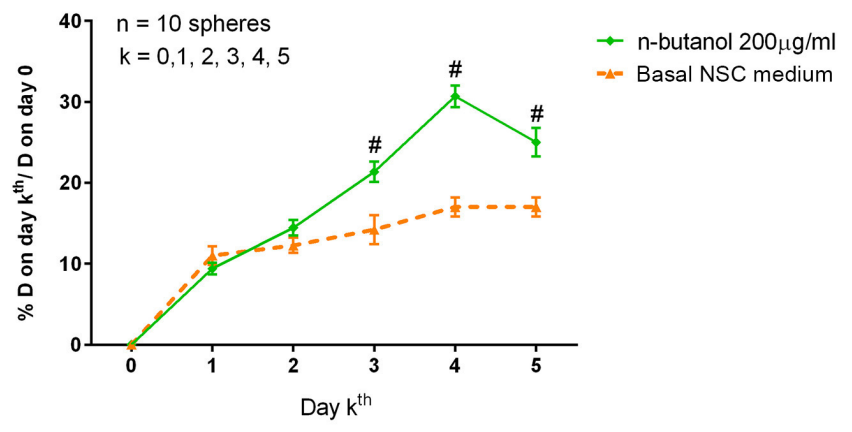

C

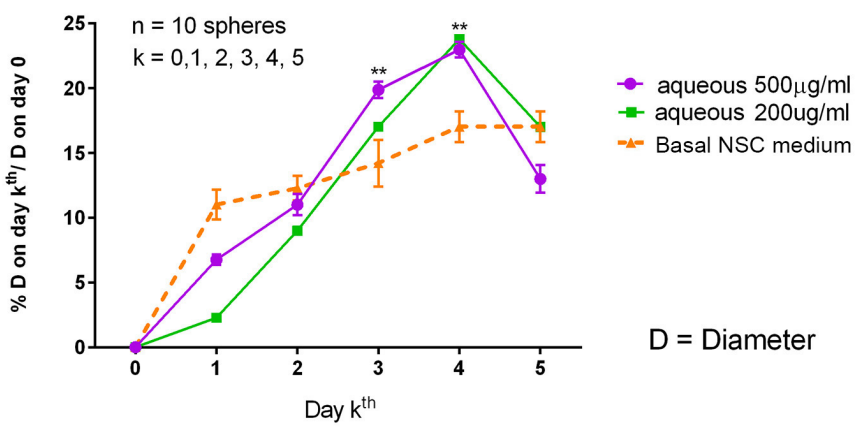

Figure 6: Diameter growth rate of cultured neurospheres the growth percentage is presented as mean \pm SEM ( $\left.{ }^{* *} p<0.1 ; \# p<0.001\right)$. 


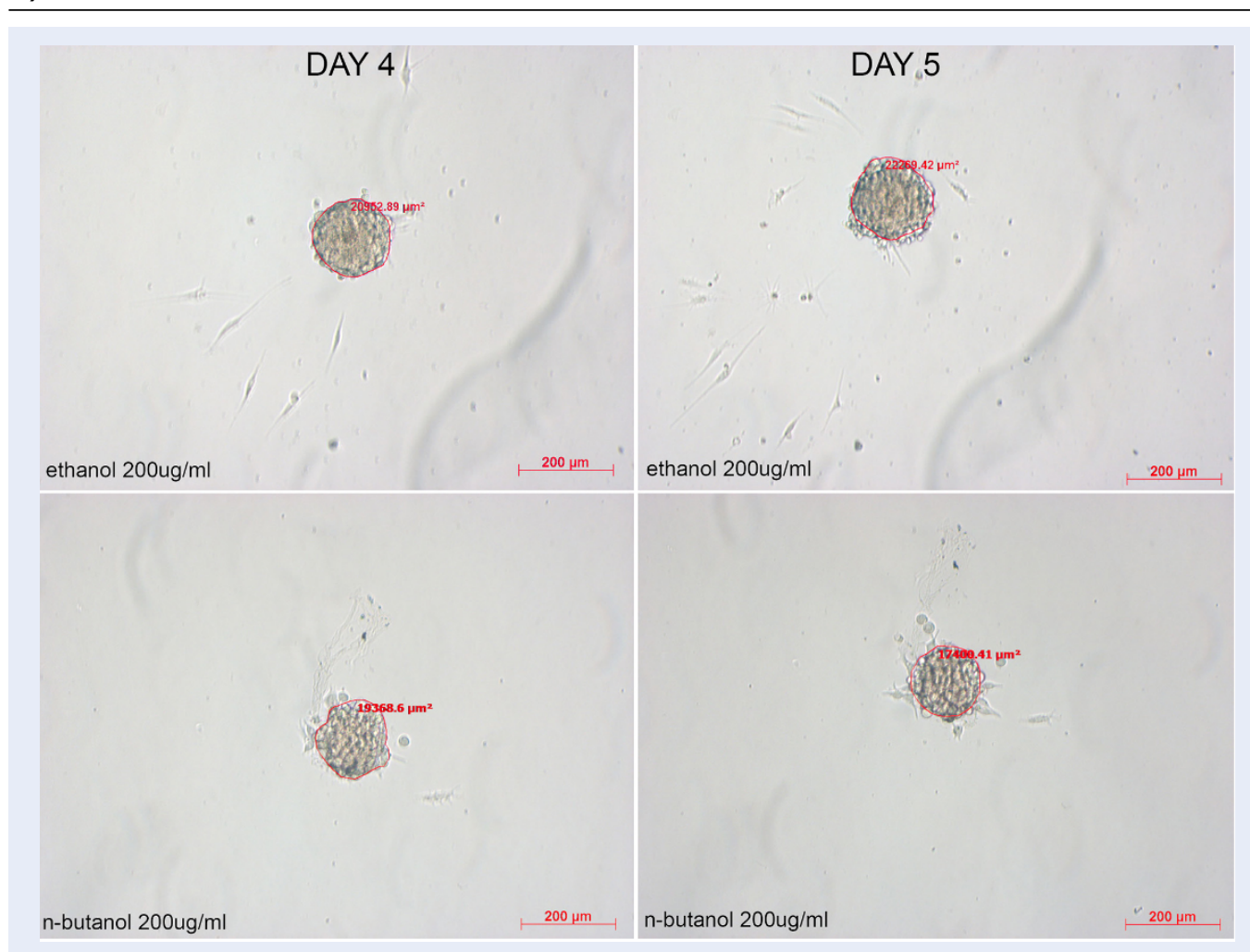

Figure 7: Neurosphere integrity when treated with $200 \mu \mathrm{g} / \mathrm{mL}$ ethanol or $\boldsymbol{n}$-butanol fraction after 5 days. Spheres treated with $n$-butanol fraction at $200 \mu \mathrm{g} / \mathrm{mL}$ lost their intact structure and cells began to detach from the sphere, adhering to the surface in shape of flatten or round cells around the sphere.

Ethanol fraction of Panax vietnamensis 200 $\mu \mathrm{g} / \mathrm{mL}$ elevated $\mathrm{G} 2 / \mathrm{M}$-phase cells and cell cycle-related genes

For further analysis on the gene expression and cell cycle, $200 \mu \mathrm{g} / \mathrm{mL}$ was chosen as the only concentration of each ginseng fraction. The G2/M percentage of the ethanol fraction neurospheres was $28.73 \pm 0.44 \%(\mathrm{p} \leq 0.001)$ and aqueous fraction was $25.85 \pm 0.71 \%(\mathrm{p} \leq 0.01)$. For comparison, the basal NSC medium had $16.88 \pm 2.76 \%$ G2/M. The proportion of G0/G1 phase declined in all fractiontreated groups compared with that of basal NSC medium ( $\mathrm{p} \leq 0.0001$ ); the most significant was that of $n$-butanol fraction-treated spheres $(28.643 \pm 1.63 \%$, $\mathrm{p} \leq 0.0001) . \quad n$-butanol fraction-treated spheres had $51.2 \pm 0.93 \%$ cells in $\mathrm{S}$ phase $(\mathrm{p}<0.001)$, but not significantly increase the proportion of G2/M-phase cells (20.20 $\pm 0.71 \%$ ) (Figure 9 A).

Treating neurospheres with $200 \mu \mathrm{g} / \mathrm{mL}$ ethanol fraction significantly elevated the mRNA levels compared with those of the basal NSC medium: ki67 (4.605 \pm 6.48 fold-change), $c y c C(9.53 \pm 2.63$ foldchange), $\quad c y c D 1 \quad(22.47 \pm 8.18$ fold-change), $c y c A 1$
(12.61 \pm 4.65 fold-change). However, there was a down-regulation in all surveyed genes compared with the basal NSC medium when treating spheres with the $n$-butanol or aqueous fraction (Figure $9 \mathbf{B}$ ).

Maintaining high level of sox 2 and gfap expression as treating neurospheres with Panax vietnamensis ethanol fraction at 200 $\mu \mathbf{g} / \mathbf{m L}$

To evaluate the differentiation effect of the ginseng fractions, neurospheres were cultured in EGF- and bFGF-free media, with the ginseng fraction added for five days. In addition, NGF $(5 \mu \mathrm{g} / \mathrm{mL})$ was also added as the positive control in the differentiation assay. In this study, there was a high mRNA level of sox2 (71.25 \pm 27.24 fold-change) and gfap (73.55 \pm 47.14 fold-change) as treating spheres with $200 \mu \mathrm{g} / \mathrm{mL}$ ethanol fraction. These levels were significantly different compared with those treated with the $n$-butanol fraction (sox2: $4.62 \pm 4.72$ foldchange, $\mathrm{p}<0.05 ;$ gfap: $0.85 \pm 1.02$ fold-change, $\mathrm{p}<0.01$ ) and aqueous fraction (sox2: $5.77 \pm 1.44$ fold-change, $\mathrm{p}<0.05 ; g f a p: 0.66 \pm 0.20, \mathrm{p}<0.05)$. The map2 mRNA 


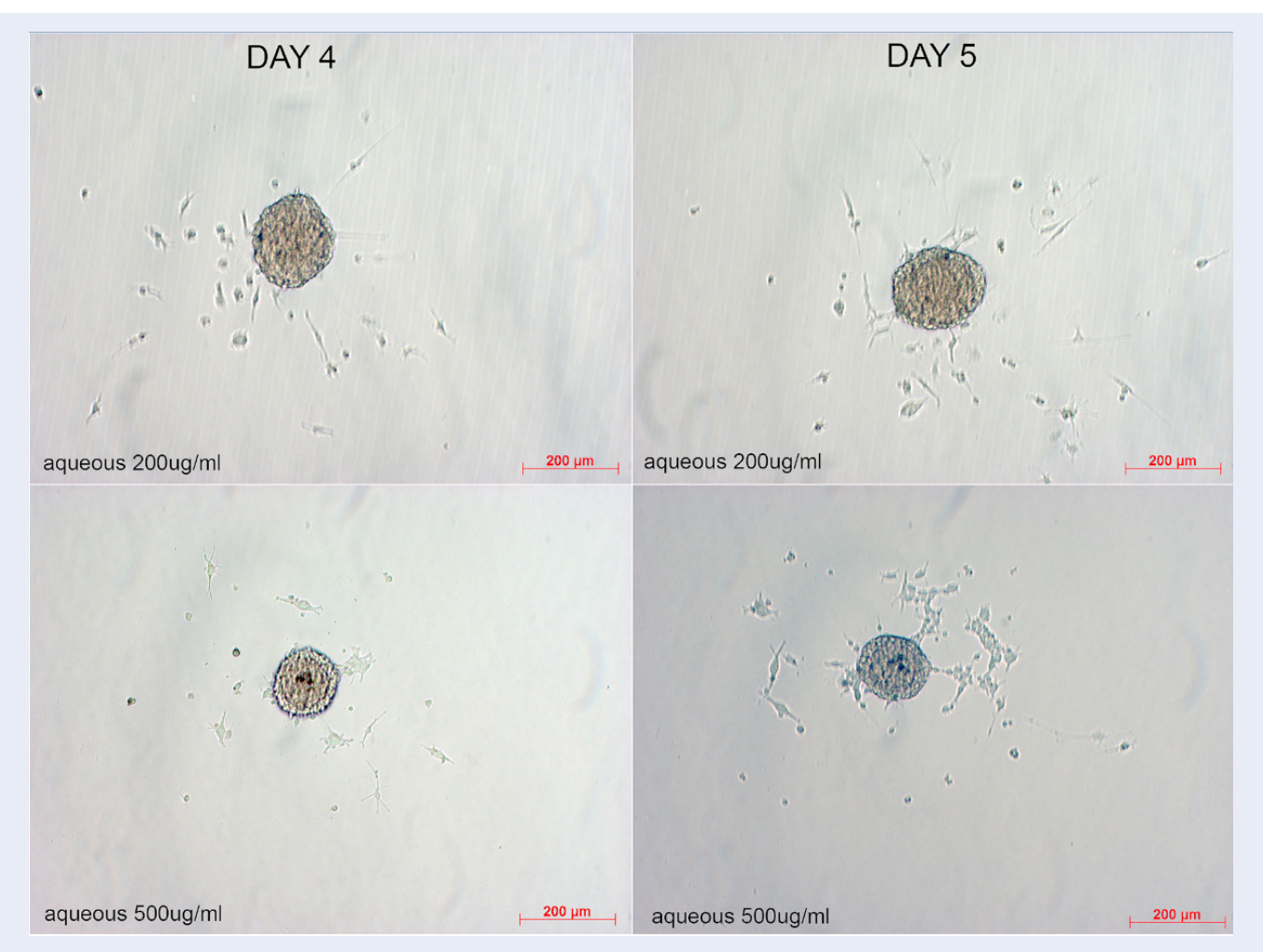

Figure 8: Day 4 and 5 neurosphere structure treated with the aqueous fraction at $500 \mu \mathrm{L} / \mathrm{mL}$.
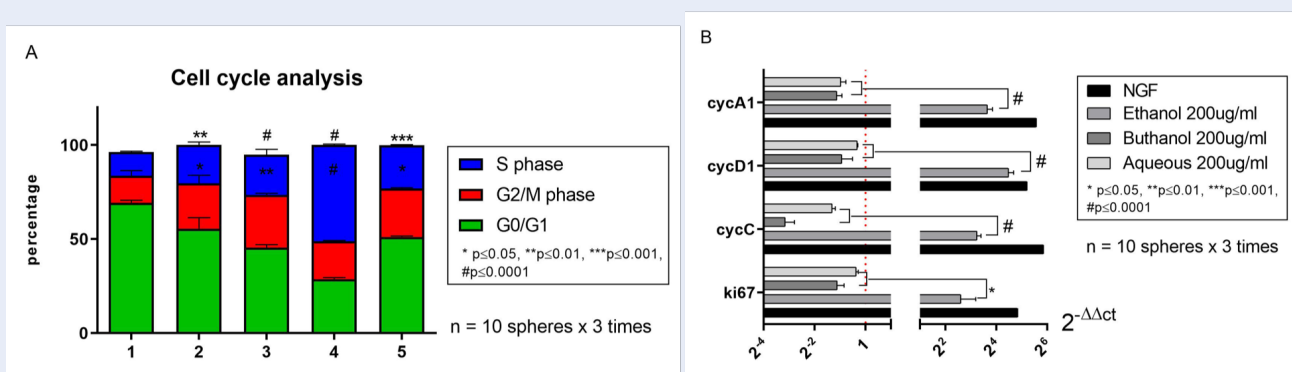

Figure 9: A. Cell cycle analysis (1) Basal NSC medium, (2) Nerve growth factor (NGF) $5 \mu \mathrm{g} / \mathrm{mL}$, (3) P. vietnamensis ethanol fraction $200 \mu \mathrm{g} / \mathrm{mL}$, (4) P. vietnamensis $n$-butanol fraction $200 \mu \mathrm{g} / \mathrm{L}$ (5) P. vietnamensis aqueous fraction $200 \mu \mathrm{g} / \mathrm{mL}$. Percentage values are mean \pm SEM. B. Proliferation mRNA expression. Graph showing mean \pm SEM of $2^{-d d C t}$ of proliferation gene mRNAs in treatment groups normalized to the basal NSC medium control. Dotted line refers to the 1 -fold change.

level in ethanol fraction-treated neurospheres was

up-regulated (4.605 \pm 3.33$)$, but not statistically different from that in other groups. Interestingly, the $m b p$ mRNA level of all treatment groups were down-regulated as compared with the negative control (Figure 10).

\section{DISCUSSION}

In this study, cultured neural stem cells could persistently generate secondary spheres through 4 passages, and strongly expressed nestin and CD24, markers for neural lineage ${ }^{25,26}$. Neural stem/progenitor cells could differentiate to 3 distinct types in the neural lineage: neurons, astrocytes and oligodendrocytes ${ }^{27}$. Cells from neurospheres could be induced to differentiate into the GFAP-positive astrocyte-like cells ${ }^{28}$, 


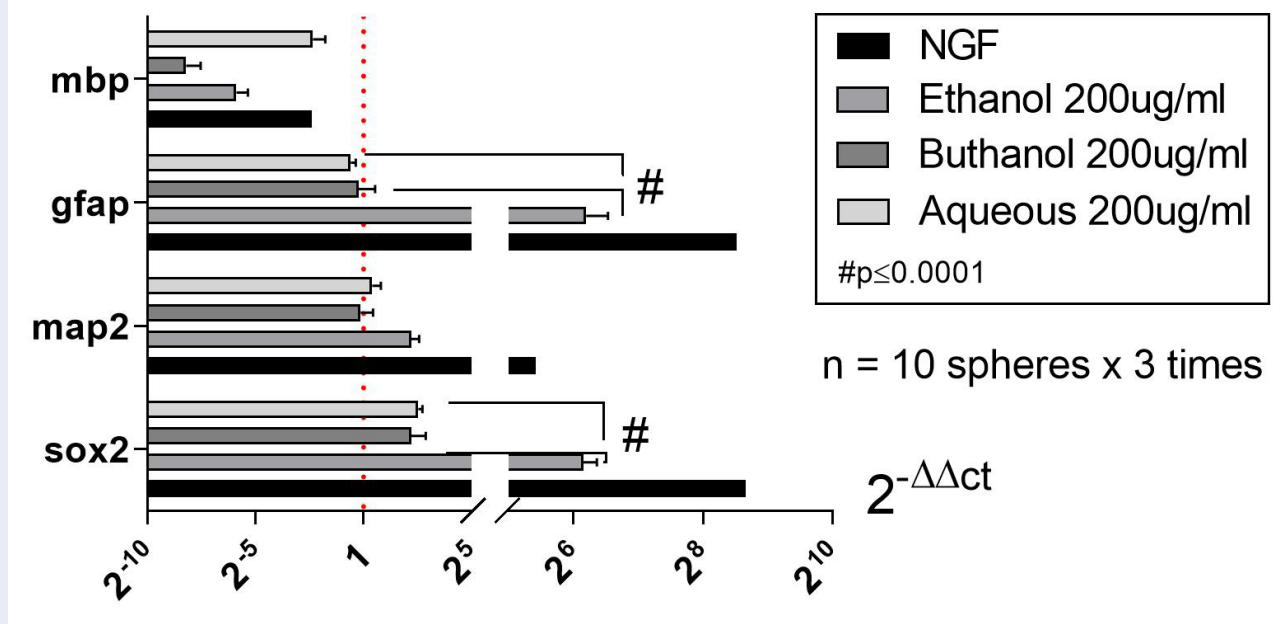

Figure 10: Differentiation mRNA expression. Graph showing mean $\pm \mathrm{SEM}$ of $2^{-d d C t}$ of differentiation gene $\mathrm{mR}$ NAs in treatment groups normalized to the basal NSC medium control: sox2 - neural stemness, map2- mature neuron, gfap - astrocyte, $m b p$ - oligodendrocyte. Dotted line refers to the 1-fold change.

further confirming the expression of GFAP protein, which was previously mentioned by mRNA expression in our previous study ${ }^{23}$.

Our results show that ginseng extract fractions significantly promoted the neurosphere growth. Normally, quiescient cells predominantly present in cultured neurospheres ${ }^{29}$, which was confirmed by the high proportion of G0/G1 in those cultured with the basal NSC medium. When treating neurospheres with ginsenosides, it was shown that they promote the growth rate of neurospheres both in vitro and in vivo ${ }^{30,31}$. In this study, the $P$. vietnamensis ethanol fraction particularly enhanced the proliferation of neural stem cells compared with other fractions. Interestingly, there was a similar pattern between ethanol fraction- and NGF-treated neurospheres: up-regulated mRNA levels of proliferating genes and high G2/M proportion. In the presence of EGF and bFGF, nerve-growth factor (NGF) increases the number of nestin ${ }^{+}$cells and promotes the survival and proliferation of neural stem cells $^{32,33}$. Ginsenosides were shown to enhance the expression of the neurotrophic receptor such as p75, p21, TrkA in Neuro-2a cells ${ }^{34}$ as well as elevate NGF and BDGF levels in cultured Schwann cells ${ }^{35}$. This suggest that the ethanol fraction might have similar effects of NGF on proliferating neurospheres.

In the differentiation assay, there was also a similar pattern between ethanol fraction- and NGF-treated neurospheres. Interestingly, our results indicated upregulation of $c y c D 1$ mRNA and decrease in G0/G1 population effect in the proliferation assay (shown above), which suggests neurogenesis inhibition while self-renewal promotion ${ }^{36}$. This was correlated with the high sox2 mRNA level in the absence of EGF and bFGF coming from actively self-renewal cells ${ }^{37}$. In addition, actively proliferating neurospheres would contain $\mathrm{GFAP}^{+}$core due to being partly isolated from mitogens ${ }^{38,39}$, correlating with the high mRNA level of $g f a p$ when eliminating EGF and bFGF from the medium. In this study, the ethanol fraction-treated neurospheres were more condensed than those with $n$-buthanol fraction indicating an increase in the size of individual cells rather than the cell number. This was consistent with a significantly high level of Sphase cells but low level of ki67 and $c y c C$ mRNA in $n$-butanol fraction-treated neurospheres ${ }^{40}$. As treating neurospheres with the aqueous fraction, low cycC mRNA level and S-phase proportion suggest that treated cell poorly entered active stages. With the presence EGF and bFGF in culture media, it's noteworthy that the ginseng $n$-buthanol or aqueous fraction might have inhibiting effect on the neural stem cell proliferation.

Previous studies on Panax vietnamensis extract already presented its new ginsenosides and other bioactive substances ${ }^{10,41}$ as well as its in vivo effects on the nervous system ${ }^{22}$. Others already pointed out positive effects of Panax ginseng extract/ginsenosides on nervous system in vivo of increasing SOX2 expression and promoting hippocampal proliferation ${ }^{14,42}$, 
attenuating neural stem cell scenescence ${ }^{43}$, maintaining neural stem cell proliferation in lead poisoning $^{44}$. Because neural stem/progenitor cells still reside in the body, many questions concerning specific mechanisms of ginseng extract/ginsenosides still remain. Using an in vitro model of neurosphere, for the first time this study has provided new insights into proliferative and differentiative effects of the ginseng extract fractions, particulaly the ethanol fraction on the neural stem cell. However, further experiments should focus into specific Panax vietnamensis ginsenosides to elucidate how the ginsenosides could promote or inhibit the neural stem cell proliferation/differentiation.

\section{CONCLUSIONS}

In this study, Panax vietnamensis extract fractions of at specific concentrations had a positive effect on the proliferation of cultured neural stem cells. The ethanol fraction at $200 \mu \mathrm{g} / \mathrm{mL}$ could significantly promote the growth rate while still sustained the integrity of treated spheres. Treated neurospheres had high levels of cell cycle mRNA expression, high proportion of the G2/M cells, as well as the percentage of G0/G1 significantly decreased. Moreover, the fraction might have similar effects as those of NGF on the differentiation of neural stem/progenitor cells. Further study should be done to elucidate the mechanism in which each ginsenoside has its effects on neural stem cells.

\section{ABBREVIATIONS}

bFGF: basic fibroblast growth factor

EGF: Epidermal growth factor

GFAP: Glial Fibrillary Acidic Protein

NGF: Nerve growth factor

NSC: Neural stem cell

\section{COMPETING INTERESTS}

The authors declare that they have no conflicts of interest.

\section{AUTHORS' CONTRIBUTIONS}

HQ Do and NH Truong carried out studies including gene-expression, flow cytometry, data analysis and manuscript composing. TT Lam, LT Nguyen, NHT Dinh and PTB Le isolated/cultured neural stem cells and tested gingseng fraction on neural spheres. LC Tran performed plant fractions for the experiment. NK Phan and PV Pham, who advised and orient the study, revised the manuscript, edited figures and checked the published data. All authors read and approved the final manuscript.

\section{ACKNOWLEDGMENT}

This study was funded by Department of Science and Technology, Ho Chi Minh city.

\section{REFERENCES}

1. Kampen JMV, Baranowski DB, Shaw CA, Kay DG. Panax ginseng is neuroprotective in a novel progressive model of Parkinson's disease. Exp Gerontol. 2014;50:95-105. PMID: 24316034. Available from: 10.1016/j.exger.2013.11.012.

2. Lee ST, Chu K, Sim JY, Heo JH, Kim M. Panax ginseng enhances cognitive performance in Alzheimer disease. Alzheimer Dis Assoc Disord. 2008;22(3):222-6. PMID: 18580589. Available from: 10.1097/WAD.0b013e31816c92e6.

3. Ji YC, Kim YB, Park SW, Hwang SN, Min BK, Hong HJ, et al. Neuroprotective effect of ginseng total saponins in experimental traumatic brain injury. J Korean Med Sci. 2005;20(2):291-6. PMID: 15832003. Available from: 10.3346/jkms.2005.20.2.291.

4. Shi YQ, Huang TW, Chen LM, Pan XD, Zhang J, Zhu YG, et al. Ginsenoside Rg1 attenuates amyloid-beta content, regulates PKA/CREB activity, and improves cognitive performance in SAMP8 mice. J Alzheimers Dis. 2010;19(3):977-89. PMID: 20157253. Available from: 10.3233/JAD-2010- 1296.

5. Liang W, Ge S, Yang L, Yang M, Ye Z, Yan M, et al. Ginsenosides $\mathrm{Rb} 1$ and $\mathrm{Rg} 1$ promote proliferation and expression of neurotrophic factors in primary Schwann cell cultures. Brain Res. 2010;1357:19-25. PMID: 20682297. Available from: 10. 1016/j.brainres.2010.07.091.

6. Zheng F, Wang H. NMDA-mediated and self-induced bdnf exon IV transcriptions are differentially regulated in cultured cortical neurons. Neurochem Int. 2009;54(5-6):385-92. PMID: 19418634. Available from: 10.1016/j.neuint.2009.01.006.

7. Li YB, Wang Y, Tang JP, Chen D, Wang SL. Neuroprotective effects of ginsenoside Rg1-induced neural stem cell transplantation on hypoxic-ischemic encephalopathy. Neural Regen Res. 2015;10(5):753-9. PMID: 26109949. Available from: 10.4103/1673-5374.156971.

8. Xu FT, Li HM, Yin QS, Cui SE, Liu DL, Nan H. Effect of ginsenoside $\mathrm{Rg} 1$ on proliferation and neural phenotype differentiation of human adipose-derived stem cells in vitro. Can J Physiol Pharmacol. 2014;92(6):467-75. PMID: 24873669. Available from: $10.1139 /$ cjpp-2013-0377.

9. Duong QHT, Nguyen PTV, Nguyen HTT, Nguyen DM. Effects of ocotillol-type saponins majonoside-R1 and vina-ginsenoside$\mathrm{R} 2$ on abrogating depression and neuronal oxidative stress in socially isolated depression mouse model. International Journal of Applied Research in Natural Products. 2016;9:27-32.

10. Yamasaki K. Bioactive saponins in vietnamese ginseng, panax vietnamensis. Pharm Biol. 2000;38(sup1):16-24. PMID: 23531134. Available from: 10.1076/phbi.38.6.16.5956.

11. Huong NT, Murakami $Y$, Tohda M, Watanabe $H$, Matsumoto $\mathrm{K}$. Social isolation stress-induced oxidative damage in mouse brain and its modulation by majonoside-R2, a Vietnamese ginseng saponin. Biol Pharm Bull. 2005;28(8):1389-93. PMID: 16079480. Available from: 10.1248/bpb.28.1389.

12. Nguyen MD, Nguyen TN, Kasai R, Ito A, Yamasaki K, Tanaka O. Saponins from Vietnamese ginseng, Panax vietnamensis $\mathrm{Ha}$ et Grushv. Collected in central Vietnam. I. Chem Pharm Bull (Tokyo). 1993;41(11):2010-4. PMID: 8293525. Available from: 10.1248/cpb.41.2010.

13. Peña IJD, Kim HJ, Botanas CJ, de la Peña JB, Le THV, Nguyen $M D$, et al. The psychopharmacological activities of Vietnamese ginseng in mice: characterization of its psychomotor, sedative-hypnotic, antistress, anxiolytic, and cognitive effects. J Ginseng Res. 2017;41(2):201-8. PMID: 28413325. Available from: 10.1016/j.jgr.2016.03.005.

14. Zhu J, Mu X, Zeng J, Xu C, Liu J, Zhang M. Ginsenoside Rg1 prevents cognitive impairment and hippocampus senescence in a rat model of D-galactose-induced aging. PLoS One. 2014;9(6):e101291. PMID: 24979747. Available from: 10.1371/journal.pone.0101291. 
15. Davis SF, Hood J, Thomas A, Bunnell BA. Isolation of adult rhesus neural stem and progenitor cells and differentiation into immature oligodendrocytes. Stem Cells Dev. 2006;15(2):1919. PMID: 16646665. Available from: 10.1089/scd.2006.15.191.

16. Vishwakarma SK, Bardia A, Tiwari SK, Paspala SA, Khan AA. Current concept in neural regeneration research: NSCs isolation, characterization and transplantation in various neurodegenerative diseases and stroke: A review. J Adv Res. 2014;5(3):277-94. PMID: 25685495. Available from: 10.1016/j. jare.2013.04.005

17. Rietze RL, Reynolds BA. Neural stem cell isolation and characterization. Methods Enzymol. 2006;419:3-23. PMID 17141049. Available from: 10.1016/S0076-6879(06)19001- 1 .

18. Fang Y, Eglen RM. Three-Dimensional Cell Cultures in Drug Discovery and Development. SLAS discovery: advancing life sciences R \& D. 2017;22(5):456-472. PMID: 26972892.

19. Ko KR, Frampton JP. Developments in 3D neural cell culture models: the future of neurotherapeutics testing? Expert Rev Neurother. 2016;16(7):739-41. PMID: 1553558. Available from: $10.1586 / 14737175.2016 .1166053$.

20. Reynolds BA, Weiss S. Generation of neurons and astrocytes from isolated cells of the adult mammalian central nervous system. Science. 1992;255(5052):1707-10. Available from: $10.1126 /$ science. 1553558 .

21. Ferrari D, Binda E, Filippis LD, Vescovi AL. Isolation of neural stem cells from neural tissues using the neurosphere technique. Curr Protoc Stem Cell Biol. 2010;Chapter 2(Unit2D.6). Available from: 10.1002/9780470151808.sc02d06s15.

22. Nguyen TT, Matsumoto K, Yamasaki K, Nguyen MD, Nguyen TN, Watanabe H. Crude saponin extracted from Vietnamese ginseng and its major constituent majonoside-R2 attenuate the psychological stress- and foot-shock stressinduced antinociception in mice. Pharmacol Biochem Behav. 1995;52(2):427-32. PMID: 8577811. Available from: 10.1016/ 0091-3057(95)00133-H.

23. Nhung HT, Dinh NTH, Le DM, Nguyen LT, Lam TT, Phan NK, et al. Isolation and culture of neural stem cells from murine foetal brain. Res Opin Anim Vet Sci. 2014;4(1):24-29.

24. Zheng XS, Yang XF, Liu WG, Shen G, Pan DS, Luo M. A novel method for culturing neural stem cells. In Vitro Cell Dev Biol Anim. 2007;43(5-6):155-8. PMID: 17619224. Available from: 10.1007/s11626-007-9035-3.

25. Pruszak J, Ludwig W, Blak A, Alavian K, Isacson O. CD15, CD24, and CD29 define a surface biomarker code for neural lineage differentiation of stem cells. Stem Cells. 2009;27(12):2928-40. PMID: 19725119. Available from: 10.1002/stem.211.

26. Ernst $C$, Christie BR. The putative neural stem cell marker, nestin, is expressed in heterogeneous cell types in the adult rat neocortex. Neuroscience. 2006;138(1):183-8. PMID: 16343784. Available from: 10.1016/j.neuroscience.2005.10. 065.

27. Gage FH. Mammalian neural stem cells. Science. 2000;287(5457):1433-8. PMID: 10688783. Available from: 10.1126/science.287.5457.1433.

28. Bernal A, Arranz L. Nestin-expressing progenitor cells: function, identity and therapeutic implications. Cell Mol Life Sci. 2018;75(12):2177-95. PMID: 29541793. Available from: 10 1007/s00018-018-2794-z.

29. Hulspas R, Quesenberry PJ. Characterization of neurosphere cell phenotypes by flow cytometry. Cytometry. 2000;40(3):245-50. PMID: 10878568. Available from: 10.1002/ 1097-0320(20000701)40:3<245::AID-CYTO10>3.0.CO;2-5.

30. Shen LH, Zhang JT. Ginsenoside Rg1 promotes proliferation of hippocampal progenitor cells. Neurol Res.
2004;26(4):422-8. PMID: 15198871. Available from: 10.1179/ 016164104225016047.

31. Lin T, Liu Y, Shi M, Liu X, Li L, Liu Y, et al. Promotive effect of ginsenoside $\mathrm{Rd}$ on proliferation of neural stem cells in vivo and in vitro. J Ethnopharmacol. 2012;142(3):754-61. PMID: 22683911. Available from: 10.1016/j.jep.2012.05.057.

32. Cattaneo E, McKay R. Proliferation and differentiation of neuronal stem cells regulated by nerve growth factor. Nature. 1990;347(6295):762-5. PMID: 2172829. Available from: 10. $1038 / 347762 \mathrm{a} 0$.

33. Lachyankar MB, Condon PJ, Quesenberry PJ, Litofsky NS, Recht $\mathrm{LD}$, Ross AH. Embryonic precursor cells that express Trk receptors: induction of different cell fates by NGF, BDNF, NT-3, and CNTF. Exp Neurol. 1997;144(2):350-60. PMID: 9168835. Available from: 10.1006/exnr.1997.6434.

34. Kim MS, Yu JM, Kim HJ, Kim HB, Kim ST, Jang SK, et al. Ginsenoside $\mathrm{Re}$ and $\mathrm{Rd}$ enhance the expression of cholinergic markers and neuronal differentiation in Neuro-2a cells. Biol Pharm Bull. 2014;37(5):826-33. PMID: 24599032. Available from: 10.1248/bpb.b14-00011.

35. Liang W, Ge S, Yang L, Yang M, Ye Z, Yan M, et al. Ginsenosides $\mathrm{Rb} 1$ and $\mathrm{Rg} 1$ promote proliferation and expression of neurotrophic factors in primary Schwann cell cultures. Brain Res. 2010;1357:19-25. PMID: 20682297. Available from: 10. 1016/j.brainres.2010.07.091.

36. Lange C, Huttner WB, Calegari F. Cdk4/cyclinD1 overexpression in neural stem cells shortens $\mathrm{G} 1$, delays neurogenesis and promotes the generation and expansion of basal progenitors. Cell Stem Cell. 2009:5(3):320-31. PMID: 19733543. Available from: 10.1016/j.stem.2009.05.026.

37. Graham V, Khudyakov J, Ellis P, Pevny L. SOX2 functions to maintain neural progenitor identity. Neuron. 2003;39(5):74965. PMID: 12948443. Available from: 10.1016/S0896-6273(03) 00497-5.

38. Campos LS, Leone DP, Relvas JB, Brakebusch C, Fässler R, Suter $\mathrm{U}$, et al. Beta1 integrins activate a MAPK signalling pathway in neural stem cells that contributes to their maintenance. Development. 2004;131(14):3433-44. PMID: 15226259. Available from: 10.1242/dev.01199.

39. Campos LS. Neurospheres: insights into neural stem cell biology. J Neurosci Res. 2004;78(6):761-9. PMID: 15505793. Available from: 10.1002/jnr.20333.

40. Ren S, Rollins BJJC. Cyclin C/cdk3 promotes Rb-dependent G0 exit. Cell. 2004;117(2):239-51. PMID: 15084261. Available from: $10.1016 / \mathrm{s} 0092-8674(04) 00300-9$.

41. Tran QL, Adnyana IK, Tezuka Y, Nagaoka T, Tran QK, Kadota S Triterpene saponins from Vietnamese ginseng (Panax vietnamensis) and their hepatocytoprotective activity. J Nat Prod. 2001;64(4):456-61. PMID: 11325227. Available from: 10.1021/ np000393f.

42. Shen LH, Zhang JT. Ginsenoside Rg1 promotes proliferation of hippocampal progenitor cells. Neurol Res. 2004;26(4):422-8. PMID: 15198871. Available from: 10.1179/ 016164104225016047.

43. Chen L, Yao H, Chen X, Wang Z, Xiang Y, Xia J, et al. Ginsenoside Rg1 Decreases Oxidative Stress and Down-Regulates Akt/mTOR Signalling to Attenuate Cognitive Impairment in Mice and Senescence of Neural Stem Cells Induced by DGalactose. Neurochem Res. 2018;43(2):430-40. PMID: 29147958. Available from: 10.1007/s11064-017-2438-y.

44. Wang B, Feng G, Tang C, Wang L, Cheng H, Zhang Y, et al. Ginsenoside Rd maintains adult neural stem cell proliferation during lead-impaired neurogenesis. Neurol Sci. 2013;34(7):11818. PMID: 23073826. Available from: 10.1007/s10072-012-1215- 